\title{
The Diagnostic Applications Of Saliva- A Review
}

\author{
${ }^{1}$ Dr Swathi V, ${ }^{2}$ Dr.Abhishek Jha, ${ }^{3}$ Dr Mamtha \\ Senior lecturer Department of Public health dentistry Krishnadevaraya college of dental sciences and hospital \\ Bangalore, Karnataka, India. \\ Senior lecturer Department of Public health dentistry New horizon dental college and research institute \\ Bilaspur, chattisgarh,India \\ Postgraduate, Department of Public health dentistry, V S dental College and Hospital Bangalore, Karnataka, \\ India.
}

\begin{abstract}
Saliva a biological fluid serves as the diagnostic tool in health and disease. Saliva is a complex fluid consisting of secretions from the major and minor salivary glands. Gland-specific saliva can be used to diagnose any pathology from the specific major salivary gland. Saliva as a diagnostic fluid offers distinctive advantages over serum as it can be collected non-invasively by individuals with modest trainingand also costeffective approach for the screening of large populations. Hence this review aimed to explore the diagnostic applications of saliva inoral, systemic diseases, infectious, autoimmune diseases also in monitoring hormone and drug levels.
\end{abstract}

Keywords: saliva, disease, diagnosis, biomarkers, caries

\section{Introduction}

Saliva is an aqueous fluid found in the oral cavity, composed of a complex mixture of secretory products (organic and inorganic products) from the salivary glands and other substances coming from the oropharynx, upper airway, gastrointestinal reflux, gingival sulcus fluid, food deposits, and blood-derived compounds.Saliva is one of the most complex, versatile, and important body fluids, supplying a large range of physiological needs. ${ }^{1,2}$ Saliva has been used in diagnostics for more than 2000 years. Saliva has been called as a mirror of the body's health as it contains the serum constituents that are measured in standard blood tests to monitor health and diseases. ${ }^{3}$ Like blood, saliva is a complex fluid containing a variety of enzymes, hormones, antibodies, antimicrobial constituents, and growth factors. Many of these enter saliva from the blood by passing through the spaces between cells by transcellular ${ }^{4,5}$ (passive intracellular diffusion and active transport) or paracellular routes (extracellular ultrafiltration). Therefore, saliva is functionally equivalent to serum, but its low concentration compared with the levels in the blood may prevent salivary diagnostics from being clinically practical; however, with the development of new and highly sensitive techniques (e.g. molecular diagnostics, nanotechnology), the low concentration of analytes in saliva is no longer a limitation. ${ }^{6}$

There is considerable excitement surrounding the application of saliva-based diagnostics for oral diseases, and this will soon be followed by application of highly informative salivary biomarkers to other highimpact systemic disorders because saliva is composed of various molecules that are filtered, processed, and secreted from the vasculature that nourish the salivary glands . This realization will enable scientists to bridge oral health research with systemic disease diagnosis. ${ }^{7,8}$

Hence the purpose of this article is to review the literature on the diagnostic applications of saliva in dental caries, periodontal diseases ,oral cancer, hereditary disorders, autoimmune diseases, and infectious diseases, , as well as in the assessment of therapeutic levels of drugs and the monitoring of illicit drug use, and also for forensic evidence and others. It also discusses the importance in public health.

\section{Composition And Functions Of Saliva}

The composition of saliva from different glands varies and it is difficult to determine the exact composition of saliva in contact with either teeth or mucosa as it's a tedious process to collect saliva under physiologic conditions. Hence it is impossible to give a satisfactory quantitative account of salivary composition in man. Saliva has $99.5 \%$ waterand $0.5 \%$ solids consisting of Organic and inorganic constituents. ${ }^{9}$ The parotid gland secretes a watery saliva rich in enzymes such as amylase, protein and glycoproteins. The sub mandibular gland contains higher proportion of glycosylated substances such as mucin. The sublingual gland produces a viscous saliva rich in mucin. ${ }^{10}$ Daily secretion rates range between 500 and700 $\mathrm{ml}$, and the average volume in the mouthis $1.1 \mathrm{ml}$. Saliva production is controlled bythe autonomic nervous system. At rest, thesecretion ranges from 0.25 to $0.35 \mathrm{ml} /$ minand is mostly produced by the submandibularand sublingual glands. ${ }^{11}$

Functions of saliva ${ }^{12}$

\begin{tabular}{|l|lr|}
\hline components & Functions & \\
\hline DOI: $10.9790 / 0853-15090996101$ & www.iosrjournals.org & $96 \mid$ Page
\end{tabular}


The Diagnostic Applications Of Saliva- A Review Diagnostic Applications Of Saliva

\begin{tabular}{|l|l|}
\hline Water & Lavage \\
\hline Sakivary alpha amylase,ribonucleases,water & Digestion \\
\hline Gustin & Mediation for taste \\
\hline Mucin,statherin,water & Lubrication \\
\hline Bicarbonates,phosphate,proteins & Buffer \\
\hline Fluorideion,calcium,statherin & Promote remineralization \\
\hline $\begin{array}{l}\text { SIgA,lactoferrin,lysozyme,lactoperoxidase,cystatins,histatins,mucins,amylase, } \\
\text { defensins }\end{array}$ & Antimicrobial,antiviral and antifungal activity \\
\hline Water,mucins,electrolytes & Maintenance of oral mucosa \\
\hline
\end{tabular}

Advantages of Saliva as Investigatory Medium ${ }^{13,14}$

1.) Saliva can be collected without breaking the skin or entering the body in any other way, it has obvious advantages for multiple non-invasive collections

2.) Easy for obtaining samples from those whom, for cultural reasons or age or because of physical or mental handicaps, it would be unethical to collect blood samples.

3.) The steroid hormones in saliva are thought to reflect the free hormone concentration. Therefore, saliva levels are a more accurate reflection of the active hormone in the body, especially for steroid hormones, which are strongly bound in blood by specific binding globulins

4.) Many of the hazards associated with blood collection do not apply to saliva. There is no need for sharps, which have the potential for cross contamination among patients when used improperly and present a danger to health care personnel.

5.) Because of the low concentrations of antigens in saliva, HIV and hepatitis infections are much less of a danger from saliva than from blood

6.) Convenient for multisampling, compared to blood and urine, saliva is also cheaper to store and ship. In addition saliva does not clot and can be manipulated more easily than blood.

\section{Disadvantages $^{15}$}

1.)Saliva has proteins as biomarkers to diagnose diseases - that are there in concentrations that are much less than in serum and in whole blood.

2. Salivary composition can be influenced by the method of collection and degree of stimulation of salivary flow.

3.Many serum markers can reach whole saliva in an unpredictable way (i.e. gingival crevicular fluid flow and through oral wounds). These parameters will affect the diagnostic usefulness of many salivary constituents.

4. Whole saliva also contains proteolytic enzymes derived from the host and from oral microorganisms. These enzymes can affect the stability of certain diagnostic markers. Some molecules are also degraded during intracellular diffusion into saliva.

\section{Analysis Of Saliva For Diagnosing Various Diseases}

\section{Saliva And Dental Caries}

In the last few decades, there has been a focus on the utilization of saliva for bacteriological tests that give an indication of dental caries risk. In clinical practice ,measurement of saliva (sialometry) is particularly in indicated as part of the initial examination of a new patient to be treated for dental caries, during evaluation of preventive and restorative treatment of dental caries,in elderly patients who take regular medications, and /or have exposed root surfaces and as a part of the investigative procedures for suspected hyposalivation. ${ }^{16}$ Saliva also has its use in monitoring the level of oral bacteria in it. The increased numbers of Streptococcusmutansand lactobacilli in saliva have been associated with increased caries prevalence and root caries . DNA can easily be isolated from oral epithelial cells, collected by use of a buccal swab, one of the most common oral diagnostics. ${ }^{17}$ With a protective role, several salivary phosphopeptides appear to be involved in remineralization processes, delaying the loss of tooth structure. Salivary proteins like mucin plays an important role in protection of oral surfaces. Also these salivary proteins participate in acquired enamel pellicle formation, thus increase protective features of saliva. ${ }^{18}$ The flow of whole saliva is of clinical relevance for the susceptibility and activity of dental caries.Xerostomia usually appears when resting unstimulated whole salivary flow rate is less than $0.1-0.2 \mathrm{ml} /$ min and stimulated flow rate is less than $0.4-0.7 \mathrm{ml} / \mathrm{min}^{19}$

\section{Saliva And Periodontal Disease.}

Patients with periodontal disease are shown to have higher salivary concentrations of $\operatorname{Ig} \mathrm{A}, \operatorname{IgG}$ and $\operatorname{IgM}$ specific to periodontal pathogens compared with healthy patients ${ }^{20}$. Nonspecific markers like mucin , decreased concentration of MG2 in saliva may increase colonization with this periodonto- pathogen . Patients with low levels of lysozyme insaliva are more susceptible to plaque accumulation, which is considered a risk factor for periodontal disease.Lactoferrin is strongly up-regulated in mucosal secretions during gingival inflammation and 
is detected at a high concentration in saliva of patients with periodontal disease compared with healthy patients $^{21,22}$.C-reactive protein is a systemic marker released during the acute phase of an inflammatory response. High levels of C-reactive protein have been associated with chronic and aggressive periodontal diseases. Many different biomarkers associated with bone formation, resorption and turnover, such as alkaline phosphatase, osteocalcin, osteonectin and collagen telopeptidases, have been evaluated in gingival crevicular fluid and saliva. These mediators are associated with local bone metabolism (in the case of periodontitis) as well as with systemic conditions ${ }^{23}$ (such as osteoporosis or metastatic bone cancers)

\section{Saliva And Oral Cancer}

Oral cancer refers to all malignancies arising from the lips, the oral cavity, and pharynx and it affects more than 481,000 new patients worldwide. ${ }^{24}$ The $90 \%$ of oral cancers are oral squamous cell carcinoma.(OSCC) An increasing number of systemic diseases and conditions, amongst them oral cancer, have been shown to be reflected diagnostically in saliva. Moreover, using saliva as a diagnostic fluid meets the demands for inexpensive, noninvasive, and accessible diagnostic methodology ${ }^{25}$. Protein biomarkers in saliva are being analyzed both individually and as a panel of markers to aid in early detection of oral cancer and in implementing appropriate therapeutic regime.Tumor specific genomic markers consisting of DNA and RNA markers can be identified in saliva for detection of oral cancer.. In addition transcript levels of mRNA, microRNA levels are also considered as diagnostic markers for oral cancer. Detection of telomerase activity in saliva of OSCC was performed and they detected telomerase positivity in $75 \%$ of cases suggesting that telomerase detection could be used as assistant marker in OSCC. ${ }^{26}$

\section{Overexpression of Proteins in saliva in OSCC and their Functional Role ${ }^{27}$}

\begin{tabular}{|l|l|}
\hline Protein & Functions \\
\hline M2BP & Tumor antigen \\
\hline MRP14 & Calcium binding protein \\
\hline CD 59 & Enables the tumor cells to escape from complement dependent and antibody mediated killing \\
\hline Prifilin 1 & $\begin{array}{l}\text { Regulator of microfilament system and is involved in various signaling pathways Catalase Protects } \\
\text { against oxidative stress }\end{array}$ \\
\hline
\end{tabular}

\section{Saliva And Forensic Odontology}

Forensic dentistry or forensic odontology has been defined by the FDI as "that branch of dentistry which, in the interest of justice, deals with the proper handling and examination of dental evidence, and with the proper evaluation and presentation of dental findings" ${ }^{28}$ The evidence that may be derived from teeth, is the age (in children) and identification of the person to whom the teeth belong. This is done using dental records or ante-mortem (prior to death) photographs. It also provides a serologic and a genetic basis for identification in forensic odontology as ABH antigens are secreted in saliva as in other body fluids ${ }^{29}$. The first confirmatory test for human saliva is the

newRapid Stain Identification (RSID $®$ ) test for SALIVA is designed for fast, easy, and reliable detection of human saliva from a variety of samples encountered by forensic laboratories, including envelopes, glass bottles, aluminium cans, plastic lids and stained surfaces.Polymerase chain reaction (PCR) allows replication of thousands of copies of a specific DNA sequence in vitro, enabling the study of small amounts of DNA. ${ }^{30}$

\section{Saliva And Drug Monitoring}

Determination of salivary drug concentrations is one of the major domains for the application of saliva in laboratory medicine. . For a drug to appear in saliva, drug molecules in serum must pass through the salivary glands and into the oral cavity. ${ }^{31}$ Factors such as molecular size, lipid solubility, and the degree of ionization of the drug molecule, as well as the effect of salivary $\mathrm{pH}$ and the degree of protein binding of the drug, are important determinants of drug availability in saliva .only the unbound fraction of the drug in serum is available for diffusion into saliva. The unbound fraction of a drug is usually the pharmacologically active fraction. This may represent an advantage of drug monitoring in saliva in comparison with drug monitoring in serum, where both bound and unbound fractions of a drug can be detected. ${ }^{32}$

Drugs currently monitored in saliva: $:^{33}$

\begin{tabular}{|l|l|}
\hline Phenytoin & Lithium \\
\hline Primidone & Methadone \\
\hline Ethoreximide & Cyclosporine \\
\hline Carbamazepine & Marijuana \\
\hline Theophylline & Cocaine \\
\hline Caffeine & Alcohol \\
\hline
\end{tabular}

Saliva And Hormone Monitoring 
Saliva can be analyzed as part of the evaluation of endocrine function. The majority of hormones enter saliva by passive diffusion across the acinar cells. ${ }^{34}$ Most of these hormones are lipid-soluble (i.e., steroids). For neutral steroids which diffuse readily into saliva, salivary hormone levels represent the non-protein-bound (free) serum hormone levels. Furthermore, some steroid hormones can be metabolized in the salivary epithelial cells by intracellular enzymes during transcellular diffusion, which can affect the availability of these hormones in saliva $^{35}$. Salivary cortisol levels demonstrate excellent correlation with free serum cortisol levels. salivaryaldosterone levels demonstrated a high correlation with serum aldosterone levels, and increased aldosterone levels were foundin both the serum and saliva of patients with primary aldosteronism ${ }^{36}$. Salivary progesterone levels showed good correlation with serum levels during the menstrual cycle and reflected the free serum progesterone levels. Serial measurement of salivary progesterone has been used to assess ovarianfunction, for diagnosing defective or inadequate luteal function, as well as to monitor the response to hormone therapy. ${ }^{37}$

\section{Salivary Biomarkers In Cardiovascular Disease}

Salivary markers such as amylase have been used for postoperative follow-up in patients who had cardiovascular surgery. Low salivary amylase in preoperative patients with aortic aneurysm is associated withincreased mortality. ${ }^{38}$ In a case control study, the patients with acute myocardial infarction showed higher levels of creatine phosphokinase (CPK) in saliva as well as in serum. ${ }^{39}$. Salivary biomarkers have also been incorporated into POC devices for the rapid assessment of cardiovascular disease (CVD) with potential association with distinct disease stages, demonstrating promising results to identify CVD .Elevated salivary lysozyme levels, a biomarker for oral infection and hyperglycemia, has also shown a significant association with hypertension, an early stage of CVD. ${ }^{40,41}$

\section{Salivary Biomarkers For Renal Disease}

Series of salivary markers that were associated with end stage renal disease included cortisol, nitrite, uric acid, sodium, chloride, $\mathrm{pH}$, amylase and lactoferrin. ${ }^{42}$. calorimetric test strips were used to monitor salivary nitrate and uric acid before and after hemodialysis. Salivary phosphate has been successfully used as a clinical biomarker for hyperphosphatemia, which is an important contributor to cardiovascular calcification in chronic renal failure ${ }^{43}(\mathrm{CRF})$.

\section{Saliva And Autoimmune Disease}

Sialochemistry may also be used as a diagnostic test for Sjogren's syndrome. A consistent finding is increased concentration of sodium, chloride, IgA, IgG, lactoferrin, $\beta_{2}$ microglobulin, lysozyme $\mathrm{C}$, cystatin, and inflammatory mediators such as prostaglandin $\mathrm{E}_{2}\left(\mathrm{PGE}_{2}\right)$ and thromboxane $\mathrm{B}_{2}$ in the saliva of Sjogren's disease patients. ${ }^{44}$ Parotid saliva from patients with rheumatoid arthritis and Sjogren's syndrome shows high levels of tissue kallikrein. Abnormalities in microRNA expression related to inflammatory cytokines, Th-17 and regulatory T cells as well as B cells have been described in several autoimmune diseases. ${ }^{45,46}$

\section{Salivary Biomarkers For Infectious Diseases}

Antibodies against viruses, bacteria, fungal and parasite can be detected in saliva and can aid in the diagnosis of infections.Helicobacter pyloriinfection is associated with peptic ulcer disease and chronic gastritis. Polymerase chain reaction (PCR) technique has been proved to be highly sensitive and specific for detecting $\mathrm{H}$. pyloriDNA in saliva. ${ }^{47}$ In the children infected with Shigellarevealedhigher titers of anti-Shiga toxin antibody in comparisonwith healthy controls. Specific antibody to Taeniasolium larvae has been demonstrated in saliva for identification of neurocysticercosis ${ }^{48}$. Reactivation of herpes simplex virus type-1 (HSV-1) is involved in the pathogenesis of Bell's palsy, and PCR-based identification of virus DNA in saliva is a useful method for the early detection of HSV-1 reactivation in patients with Bell's palsy ${ }^{49}$. HIV Antibody to HIV in whole saliva of infected individualswas detected by ELISA and Western blot assay,correlated with serum antibody levels. ${ }^{50}$ Saliva was found to be a useful alternative to serum for the diagnosis of viral hepatitis. Acute hepatitis A (HAV) and hepatitis B (HBV) were diagnosed based on the presence of IgM antibodies in saliva. Hepatitis B virus DNA revealed by PCR in saliva. Saliva has also been used for screening for hepatitis B surface antigen (HbsAg) in epidemiological studies. ${ }^{51}$

\section{Conclusion}

The value of saliva as a diagnostic tool has long been disregarded until the advantages of saliva-based approaches was recognized in the past decade, and led to an evolution from treating saliva as a diagnostic worthlessness to promoting salivary diagnostics. With advances in microbiology, immunology and biochemistry, salivary testing in clinical and research settings is rapidly proving to be a practical and reliable means of recognizing oral signs of systemic illness and exposure to risk factors. The components of saliva act as a "mirror of the body's health," and the widespread use and growing acceptability of saliva as a diagnostic tool is helping 
individuals, researchers, health care professionals and community health programs to better detect and monitor disease and to improve the general health of the public.Due to its many potential advantages, salivary diagnosis provides an attractive alternative to more invasive, time-consuming, complicated, and expensive diagnostic approaches. Based on the abundance of promising research efforts and the fact that research into salivary diagnostics is currently a priority, saliva-based diagnostics present unparalleled opportunities for research and commercialization opportunities. With the current rate of progression, salivary diagnostics can become a key player in routine health monitoring in the near future and enable the early detection of disease using a simple and effective assay. Thus, salivary diagnostics will not only save lives, but also preserve the quality of lives that have been saved.

\section{References}

[1]. Daniela Pereira Lima , Diego Garcia Diniz,SuzelyAdasSalibaMoimaz. Saliva: Reflection of the body International Journal of Infectious Diseases 2010;(14) 184-188

[2]. Mandel ID. The role of saliva in maintaining oral Homeostasis. J Am Dent Assoc 1989; 119: 298-304.

[3]. Dodds MW, Jonson DA, Yeh CK. Health benefits of saliva: A Review. J Dent 2005;33:223-33

[4]. Sreebny L. Saliva: its Role in Health and Disease. Int Dent J $1992 ; 42: 291-304$.

[5]. DeepaN.Thirruuvakkasaru . Saliva as a potential diagnostic tool. Indian journal of medical Sciences 2010,Vol-64 (7)pg293-306

[6]. Yu-Hsiang. Saliva: An emerging biofluid for early detection of diseases. Am J Dent. 2009 August ;22(4): 241-248.

[7]. Mohit Bansal and SheljaVashist . Saliva - A Diagnostic Tool . Indian J Dent Adv 2012; 4(3): 910-916

[8]. Mandel ID. Salivary diagnosis: More than a lick and a promise. J Am Dent Assoc 1993;124:85-87.

[9]. Fox PC. Saliva composition and its importance in dental health. CompendSuppl 1989;13:457-60.

[10]. Daniela Pereira Lima. Saliva: Reflection of the body International Journal of Infectious Diseases 2010 (14) e184-e188

[11]. Sue P Humphrey \&Russel T Williamson. A Review of Saliva; Normal composition, flow \& function. J. Prost Dent 2001; 85: 162 169.

[12]. George JR, Fitchen JH. Future applications of oral fluid technology. Am J Med 1997;102:21-5.

[13]. Malamud D. Salivary diagnostics: The future is now. J Am Dent Assoc 2006; 137:284- 286.

[14]. . . D K Gupta, V Singh, A Singh, R K Dubey, G B Gupta. Saliva - A non invasive diagnostic tool for aging population. Journal of the Indian Academy of Geriatrics, 2011; 7: 177-181.

[15]. A Aguirre, LA Testa-Weintraub. Sialochemistry: A diagnostic tool? Crit Rev Oral Biol Med 1993;4(3/4):343-50.

[16]. Johnson NW. Risk Markers for Oral Diseases, Vol. 1. Dental Caries. Cambridge: Cambridge University Press, 1991.

[17]. Lenander-Lumikari M, Loimaranta V. Saliva anddental caries. Adv Dent Res 2000;14:40-7

[18]. Fabian TK, Fejerdy P, Csermely P. hhemical biology of Saliva in health and disease, Wiley Encyclopedia of ChemicalBiology.New York: John Wiley \& Sons, 2008. pp. 348-358.vol.1-4.

[19]. Sreebny L, Zhu WX. Whole saliva and the diagnosis of Sjogrens syndrome: An evaluation of patients who complain of dry mouth and dry eyes. Part 1: Screening tests. Gerodontology 1996;13:35-43.

[20]. Birkedal-Hansen H. Role of matrix metalloproteinases in human Periodontal Diseases. J Periodontol 1993: 64(5 Suppl.): 474-484

[21]. Giannobile WV. C-telopeptidepyridinoline cross-links. Sensitive indicators of periodontal tissue destruction. Ann N Y AcadSci 1999: 878: 404-412.

[22]. Giannobile WV. Periodontal surveillance - implications in the promotion of public health. J Periodontol 2007: 78: 1177.

[23]. Goodson JM. Diagnosis of periodontitis by physical measurement: Interpretation from episodic disease hypothesis. J Periodontol 1992: 63(4 Suppl.): 373-382.

[24]. Nagler R, Bahar G, Shpitzer T, Feinmesser R. Concomitant analysis of salivary tumor markers-A new diagnostic tool for oral cancer. Clin Cancer Res2006 Vol. 12, No. 13, pp. 3979- 3984.

[25]. Hu.S ,Arellano M , Boontheung P, Wang, J, Zhou H et al. Salivary proteomics for oral cancer biomarker discovery. Clin Cancer Res 2008 ,.Vol. 14, No. 19, pg 6246-6252,

[26]. Liao PS, Chang YC, Huang MF, Tai KW. \& Chou, MY. Mutation of P53 gene codon 63 in saliva as a molecular marker for oral squamous cell carcinomas. OralOncol, Vol.2000 36, pp. 272-276.

[27]. Peter S. Genetic heterogenecity in saliva from patients with oral squamous cell carcinoma. J MolDiag 2000 Vol. 3, pp. 164-170.

[28]. L.F Michels. Saliva and DNA. Journal of oral sciences 1991;8: 139-161

[29]. Gelfand, John J, Sninsky, Thomas J. White PCR Protocols: A Guide to Methods and Applications . Journal of Medicine 2002;8 :99103

[30]. Erlich H.A. PCR technology: Principles and Applications for DNA amplifications. Stockton Press, 2002 pg 45-67

[31]. M G Horning, L Brown, J Nowlin, K Lertratanangkoon, P Kellaway and T E Zion. Use of saliva in therapeutic drug monitering .Clinical Chemistry February 1997 vol. 23 no. 2 157-164.

[32]. Drobitch RK, Svensson CK . Therapeutic drug monitoring in saliva. An update. Clin Pharmacokinet.1992 Nov;23(5):365-79

[33]. Patsalos PN, Berry DJ. Salivary drug monitoring .Ther Drug Monit. 2013 Feb;35(1):4-29

[34]. Rainer Haeckel and Petra HäneckeZentralkrankenhaus .Application of Saliva for Drug Monitoring An In Vivo Model for Transmembrane Transport .Eur J ClinChemClinBiochem 1996; 34:171-191

[35]. QuissellDO . Steroid hormone analysis in human saliva. Ann NY Acad Sci.1993; 694:143-145

[36]. RF McGinley. The measurement of hormones in saliva: Possibilities and Pitfalls. J Steroid Biochem1987 27:81-94 .

[37]. Richard P, Jiri S, Jana V, Edgar F, Petr M, Jindrich P, et al. Saliva as a diagnostic medium. Biomed Pap Med FacUnivPalacky Olomouc Czech Repub 2009;153:103-10

[38]. Adam DJ, Milne AA, Evans SM, Roulston JE, Lee AJ, Rucklcy CV, et al. Serum amylase isoenzymes in patients undergoing operation for ruptured and nonruptured abdominal aortic aneurysm. J VascSurg 1999:30:229-35.

[39]. Mirzaii-Dizgah I, Jafari-Sabet M. Unstimulated whole saliva creatine phosphokinase in acute myocardial infarction. Oral Dis 2011;17:597-600.

[40]. Denver RA, Tzanidis A, Martin P, Krum H. Salivary endothelin concentrations in the assessment of chronic heart failure. The Lancet 2000;355:468-9.

[41]. Foley JD III, Campbell CL, Miller CS, Sneed JD, Bailey AL, Dawson DG, et al. Identification of salivary biomarkers of acute myocardialinfarction using classification and regression tree analysis. J Am CollCardiol 2010;55;A107-E996. doi:10.1016/S07351097(10)60997-7. 
[42]. Lloyd JE, Broughton A, Selby C. Salivary creatinine assays as a potential screen for renal disease. Ann ClinBiochem 1996;33:42831.

[43]. Shasha SM, Aryeh HB, Angel A, Gutman D. Salivary content in hemodialysed patients. J Oral Med 1983;38:67-70.

[44]. Friberg B, Jonsson R, Linde A. Salivary kallikrein in Sjögren's syndrome. ClinExpRheumatol 1988;6:135-8.

[45]. Tishler M, Yaron I, Shirazi I, Yaron M. Saliva: An additional diagnostic tool in Sjögren's syndrome. Semin Arthritis Rheum 1997;27:173-9.

[46]. Michalski JP, Daniels TE, Talal N, Grey HM. b2-microglobulin and lymphocyte infiltration in Sjögren's syndrome. N Engl J Med 1975;293: 1228-31.

[47]. Li C, Ha T, Ferguson DA Jr, Chi DS, Zhao R, Patel NR, et al. A newly developed PCR assay of $H$. pylori in gastricbiopsy, saliva, and feces. . Dig Dis Sci 1996;41:2142-9.

[48]. Feldman M, Plancarte A, Sandoval M, Wilson M, Flisser A. Comparison of two assays (EIA and EITB) and two samples (saliva and serum) for the diagnosis of neurocysticercosis. Trans R Soc Trop Med Hyg 1990;84:559-62

[49]. Furuta Y, Fukuda S, Chida E, Takasu T, Ohtani F, Inuyama Y, et al. Reactivation of herpes simplex virus type 1 in patientswith Bell's palsy. J Med Virol 1998;54:162-6.

[50]. Matsuda S, Oka S, Honda M, Takebe Y, Takemori T. Characteristics of IgA antibodies against HIV-1 in sera andsaliva from HIVseropositive individuals in different clinicalstages. Scand J Immunol 1993;38:428-34.

[51]. Van de Eijk AA, Niester HG, Gotz HM, Janssen HL, Schalm SW, Osterhaus AD. Paired measurements of quantitative hepatitis B virus in saliva and serum of chronic hepatitis patients: Implications for saliva infectious agent. J ClinVirol 2004;29:92-4. 